\title{
EFFECT OF THERMAL SHOCK AND RUMINAL INCUBATION ON SEED GERMINATION IN HELIANTHEMUM APENNINUM (L.) MILL. (CISTACEAE)
}

\author{
Ana B. ROBLES y Jorge CASTRO
}

\begin{abstract}
Effect of thermal shock and ruminal incubation on seed germination in Helianthemum apenninum (L.) Mill. (Cistaceae). Here, we analyse the effect of different treatments on seed germination in Helianthemum apenninum (L.) Mill. (Cistaceae), considering scarification with sandpaper, thermal shock simulating the heat from fire, and incubation in the rumen of sheep and goat simulating passage through the gut of ruminants. Mechanical scarification boosted the germination ( $95 \%$ vs. $6 \%$ of control treatment), indicating that the seeds have a potentially high germination rate if the coat is eroded. Thermal shock did not improve germination. Incubation in rumen increased seed germination, up to a $32 \%$ after $48 \mathrm{~h}$ in ruminal liquid versus $12 \%$ for control seeds in the case of sheep. The results suggest that germination in H. apenninum, while not enhanced by heat from fires, may be enhanced by herbivore ingestion.
\end{abstract}

Key words. Dormancy, Mediterranean shrublands, ruminal digestion, thermal shock.

RESUMEN. Efecto del choque térmico y de la incubación ruminal en la germinación de semillas de Heliantemum apenninum (L.) Mill. (Cistaceae). En este trabajo se analiza el efecto que tienen diversos tratamientos sobre la germinación de las semillas de Helianthemum apenninum (L.) Mill. (Cistaceae), siendo éstos 1) la escarificación mecánica mediante abrasión con papel de lija, 2) choque térmico (que simula el efecto del fuego), y 3) incubación en el rumen de oveja y cabra (que simula el paso por el tracto digestivo del ganado). La escarificación mecánica aumentó considerablemente la germinación ( $95 \%$ vs $6 \%$ en el control), indicando una alta viabilidad de las semillas. El choque térmico no incrementó la germinación en ninguna de las combinaciones de tiempo y temperatura probadas. La incubación en el rumen incrementó el porcentaje de germinación, siendo $32 \%$ tras $48 \mathrm{~h}$ de incubación frente a $12 \%$ para el control en el caso de oveja. Los resultados sugieren que el calor producido durante un fuego no promueve la germinación de las semillas de $H$. apenninum, mientras que podría ser promovida por la ingestión de semillas por herbívoros.

Palabras clave. Arbustos mediterráneos, choque térmico, dormancia, digestión ruminal.

\section{INTRODUCTION}

Cistaceae is a family of shrubs and herbs that are characteristic of dry, sunny habitats, its main diversification centre being the
Mediterranean region (Proctor, 1978). The taxa in this family present seeds with hard coats (hardseededness, Thanos et al., 1992), which impede water imbibition and gas exchange and, therefore, seed germination (Mayer \& 
Poljakoff-Mayber, 1989; Bewley \& Black, 1994; Baskin \& Baskin, 1998). Once the seed coat is broken by some mechanism, seed germination is commonly a massive process in this family, reaching values approaching 100\% (e.g. Thanos et al., 1992; Trabaud, 1995).

Mechanisms that may break the dormancy imposed by hard coats are diverse in nature (Mayer \& Poljakoff-Mayber, 1989; Bewley \& Black, 1994; Baskin \& Baskin, 1998). Among them, thermal shock produced during fires has been reported as a particularly important one for breaking dormancy of many Cistaceae species. In fact, fires in the Mediterranean shrublands are frequently followed by massive recruitment of Cistaceae seedlings (Trabaud \& Oustric, 1989; Roy \& Sonié, 1992; Ferrandis et al., 1999), and several laboratory studies have demonstrated that thermal shock comparable to soil temperatures during a fire can promote germination in this family (González-Rabanal \& Casal, 1995; Trabaud, 1995; Castro \& Romero-García, 1999). Passage through the digestive tract of vertebrates may also promote germination of hard-coated seeds (Mayer \& Poljakoff-Mayber, 1989; Baskin \& Baskin, 1998), a mechanism which has been reported for some Cistaceae species (Malo \& Suárez, 1996), although such information is scarce for this family.

In the present work, we investigate the impact that the heat shock and the ingestion by vertebrates may have on the germination of Helianthemum apenninum (L.) Mill., a species that, like the rest of the members of Cistaceae, has hard-coated seeds (Thanos et al., 1992; Tébar et al., 1997). For this, we expose the seeds to laboratory treatments simulating i) the effect of fire (thermal shock matching the temperatures reached in the upper layer of the soil during wildfires in Mediterranean shrublands), and ii) simulating the effect of ungulate ingestion (placing seeds in the rumen of sheep and goat, which are common consumers of this plant).

\section{MATERIALS AND METHODS}

\section{The species}

Helianthemum apenninum (L.) Mill. (Cistaceae), a dwarf shrub reaching $40 \mathrm{~cm}$ in height, is a common scrubland plant in the Mediterranean Basin, growing in dry, sunny environments from sea level to $2100 \mathrm{~m}$. The fruit is a thin, woody capsule with 3 valves (4$8 \mathrm{~mm}$ in size) containing ca. 10 seeds, which are released in mid-summer (López-González, 1993; Tébar et al., 1997). The seeds are small, ca. $2 \mathrm{~mm}$ thick, and subspherical in shape. The species is palatable and heavily grazed by freeranging livestock, mainly domestic sheep and goats (Fernández, 1995), which frequently ingest ripe fruits while browsing (personal observation; see also Tébar et al., 1997).

\section{Seed treatments and germination experiments}

Ripe fruits from at least 30 Helianthemum apenninum plants were collected in July 1994 in a stand located at Natural Park of Sierra de Castril (SE Spain, 3746'30' 'N, 2 ${ }^{\circ} 46^{\prime} 24^{\prime \prime}$ W) at $1500 \mathrm{~m}$ a.s.l. Seeds were extracted from the fruits and stored in paper bags at room temperature. Germination experiments, spanning 1995, were performed in a growth chamber under a photoperiod of $16 \mathrm{~h}$ light and $8 \mathrm{~h}$ darkness. For technical reasons, the temperature of the chamber was different depending on the experiment, being either a constant temperature of $10^{\circ} \mathrm{C}$ or an alternating cycle of $15^{\circ} \mathrm{C}$ during dark periods and $20^{\circ} \mathrm{C}$ during light periods. Nevertheless, previous trials showed lack of germination differences for these two temperature regimes for control seeds (see also Martin et al. [1995] for similar results). In addition, each experiment was compared with its own control, and therefore differences in germination temperatures are not likely to affect the results.

Before starting germination test, seeds were individually examined under a dissecting 
microscope and any damaged or empty seed was discarded. Seeds were placed in Petri dishes of $9 \mathrm{~cm}$ in diameter, resting on filterpaper disks and were watered as needed with sterilised distilled water. Petri dishes were randomly repositioned within the chamber every 5 days. Germination, identified as visible protrusion of the radicle, was recorded at 4-5 days intervals. The experiments were ended when all treatments registered 10 consecutive days without germination, this occurring within 5 weeks in all the cases. We performed three different experiments.

\section{Experiment \#1. Effect of mechanical scarification}

Seeds were placed on a woody surface and were gently rubbed with sand paper until the seed coat was partially eroded. To prevent fungal attack after scarification, seeds were disinfected by immersion in a $1 \%$ sodium hypochlorite solution for $10 \mathrm{~min}$, followed by thorough rinsing with sterile distilled water. Untreated seeds were also disinfected. We used 4 replicates per treatment containing 100 seeds each. The temperature of the chamber was $15^{\circ} \mathrm{C}$ during dark periods and $20^{\circ} \mathrm{C}$ during light periods. This treatment provides valuable information on seed viability of hard-coated seeds, being a reference to compare the effectiveness of other treatments.

\section{Experiment \#2. Effect of thermal shock}

Dry seeds were placed in glass dishes and heated in an oven (precision $\pm 2^{\circ} \mathrm{C}$ ) using two different schedules. In one, temperature was kept constant at $100 \pm 2^{\circ} \mathrm{C}$ and the seeds were exposed for 10,30 or 60 minutes (treatments Th 10 to Th60). In the other procedure, exposure time was fixed at $10 \mathrm{~min}$, and the seeds were heated at $80,100,120$ or $140^{\circ} \mathrm{C}$ (treatments K80 to K140). These heat treatments were selected because they matched time and temperature ranges commonly reached in the upper layer of the soil $(2-5 \mathrm{~cm})$ during fires in
Mediterranean shrublands (Whelan, 1997), the depth where most seeds are located (Simpson et al., 1989). In addition, the temperatures selected were similar to those tested in other works that have reported a sharp increase on seed germination for other Cistaceae species (e.g. Thanos et al., 1992; Valbuena et al., 1992; Trabaud 1995; Pérez-García \& Escudero, 1997; Castro \& Romero-García, 1999). We used 4 replicates per treatment containing 100 seeds each, with the chamber temperature at $15^{\circ} \mathrm{C}$ during dark periods and $20^{\circ} \mathrm{C}$ during light periods. For treatments $\mathrm{K} 100$ and Th10, a single set of 4 replicates was used, as they represent the same conditions (seeds heated 10 $\min$ at $100^{\circ} \mathrm{C}$ ).

\section{Experiment \#3. Effect of ruminal incubation}

The effect of sheep and goat ruminal incubation was studied following the methodology proposed by Olson \& Wallander (2002). Seeds inside nylon bags $(40 \mu \mathrm{m}$ mesh) were introduced in the rumen of a fistulated sheep (Segureña race) or goat (Granadina race) and incubated for $24 \mathrm{~h}, 48 \mathrm{~h}$ and $72 \mathrm{~h}$ (two bags containing 250 seeds each per treatment), the animal having been fed with lucerne hay at maintenance level. These are the standard times used in experiments to assay the degradability of food in ruminants (Mehrez \& Osrskov, 1977), and in addition match the usual food retention times in the digestive tract of these animals (Arbiza, 1986; Gardener et al., 1993a). Seed bags were inserted into the rumen by using a permanent ruminal cannula. After ruminal incubation, each bag and its content was thoroughly washed with sterile distilled water (see Gardener et al., 1993b; Ibáñez \& Passera, 1997 for a similar procedure). Germination was tested with 5 replicates per treatment, each containing 25 seeds randomly taken from the digested pool, and the temperature of the chamber was kept constant at $10^{\circ} \mathrm{C}$ (see Martin et al., 1995). 
For each experiment, final germination percentages were submitted to a one-way ANOVA, all data being previously arcsintransformed. After ANOVAs, the means of the groups were compared with the mean of their control treatment by using Dunnett's test at alevel of 0.05 (Zar, 1996). Analyses were performed using the computer software JMP 3.2.6 (SAS Institute, 1999). Throughout the paper, values are mean $\pm 1 \mathrm{SE}$.

\section{RESULTS}

Mechanical scarification boosted germination of $H$. apenninum seeds, with values of $95.0 \pm 1.1 \%$ against $6.0 \pm 0.7 \%$ of untreated seeds $(\mathrm{F}=1546.91, \mathrm{df}=1,6, \mathrm{p}<0.0001)$.

Flash heating of the seeds at $100^{\circ} \mathrm{C}$ for variable times (Th treatments) reduced the germination percentage $(\mathrm{F}=4.29, \mathrm{df}=3,12$, $\mathrm{p}=0.0284$ ), with germination percentage tending to decreases as exposure times increased (tab. 1). Similarly, flash heating for $10 \mathrm{~min}$ at variable temperatures ( $\mathrm{K}$ treatments) also reduced germination $(\mathrm{F}=7.86, \mathrm{df}=4,15$, $\mathrm{p}=0.0013$ ), until no germination was registered at $140^{\circ} \mathrm{C}$ (tab. 1).

Seed incubation in sheep rumen enhanced germination $(\mathrm{F}=2.62, \mathrm{df}=3,16, \mathrm{p}=0.0862)$, with the maximum percentage being reached after $48 \mathrm{~h}$ in the ruminal liquid (tab. 1). Incubation in goat rumen also affected germination $(\mathrm{F}=3.74$, $\mathrm{df}=3,16, \mathrm{p}=0.0328)$, reaching the highest value after $24 \mathrm{~h}$ (tab. 1).

\section{DISCUSSION}

According to our results, the germination percentage of Helianthemum apenninum seeds was very low when no treatment was applied, with values of around $10 \%$. This percentage is similar to that reported for several Helianthemum species (Gutterman \& Agami,
1987; Thanos et al., 1992; Pérez-García et al., 1995; Escudero et al., 1997), and even lower than in previous studies on this species (Thanos et al., 1992; Martin et al., 1995; Tébar et al., 1997). However, after mechanical scarification, germination was boosted (up to $95 \%$; see also Thanos et al., 1992; Tébar et al., 1997), implying that the germination of the seeds relies on some mechanisms breaking their coats.

Thermal shock simulating the heat wave in the soil during a fire in Mediterranean shrublands has been found to promote germination in many Cistaceae species, particularly in the genus Cistus (Thanos et al. 1992; Trabaud, 1995; Castro \& Romero-García, 1999). Nevertheless, thermal treatments failed to improve seed germination in $H$. apenninum, as has been shown for other Helianthemum species in the Mediterranean region. In this sense, Thanos et al. (1992) found that seedgermination percentages of $H$. croceum and $H$. pilosum seeds were only slightly higher when heated. Similarly, Pérez-García et al. (1995) found that dry heat did not improve germination, and even killed the seeds, in $H$. polygonoides and $H$. squamatum. Therefore, germination after fires may not be a general characteristic in Cistaceae.

Seed incubation in the rumen raised germination percentages, particularly in the case of sheep, from $12.0 \%$ to $32.0 \%$. Ruminal liquid, which has a neutral $\mathrm{pH}$, contains proteolytic and cellulolytic enzymes (Prins \& Van der Vorstenbosch, 1975) that may soften the seed coat and thereby increase germination percentages. Seeds having passed from the rumen into the abomasum and duodenum are exposed to an acid medium as well as to proteolytic, amilolytic and lipolytic enzymes (Gardener et al., 1993a). This could further erode seed coats, as happens when Cistaceae seeds are exposed to acid scarification (Peña et al., 1988; Pérez-García et al., 1995; PérezGarcía \& Escudero, 1997; Castro \& RomeroGarcía, 1999), and could encourage even higher 


\begin{tabular}{|c|c|c|c|}
\hline Treatments & Mean \pm s.e. & Treatments & Mean \pm s.e. \\
\hline A) Heated at $100^{\circ} \mathrm{C}$ for: & & C) Sheep Rumen for & \\
\hline $10 \min (\operatorname{Th} 10)$ & $7.2 \pm 2.5$ & $24 \mathrm{~h}$ & $20.8 \pm 3.2$ \\
\hline $30 \min (\operatorname{Th} 30)$ & $3.5 \pm 1.0$ & $48 \mathrm{~h}$ & $32.0 \pm 7.7 *$ \\
\hline $60 \min ($ Th60) & $1.0 \pm 0.4$ & $72 \mathrm{~h}$ & $17.6 \pm 4.7$ \\
\hline Untreated seeds & $4.2 \pm 0.8$ & Untreated seeds & $12.0 \pm 2.2$ \\
\hline B) Heated $10 \mathrm{~min}$ at & & D) Goat Rumen for & \\
\hline $80{ }^{\circ} \mathrm{C}(\mathrm{K} 80)$ & $7.5 \pm 1.4$ & $24 \mathrm{~h}$ & $25.6 \pm 7.0$ \\
\hline $100^{\circ} \mathrm{C}(\mathrm{K} 100)$ & $7.2 \pm 2.5$ & $48 \mathrm{~h}$ & $17.6 \pm 3.5$ \\
\hline $120^{\circ} \mathrm{C}(\mathrm{K} 120)$ & $0.5 \pm 0.5^{*}$ & $72 \mathrm{~h}$ & $7.2 \pm 3.2$ \\
\hline $140^{\circ} \mathrm{C}(\mathrm{K} 140)$ & $0.0 \pm 0.0 *$ & & \\
\hline Untreated seeds & $4.2 \pm 0.8$ & Untreated seeds & $12.0 \pm 2.2$ \\
\hline
\end{tabular}

Table 1. Mean germination percentages ( \pm s.e.) of Helianthemum apenninum seeds after different treatments: A) seeds heated at $100^{\circ} \mathrm{C}$ for 10,30 and $60 \mathrm{~min}$ (Th treatments); B) seeds heated at $80,100,120$ and $140^{\circ} \mathrm{C}$ for 10 min (K treatments); C) seeds incubated in sheep rumen for $24 \mathrm{~h}, 48 \mathrm{~h}, 72 \mathrm{~h}$; D) seeds incubated in goat rumen for $24 \mathrm{~h}, 48 \mathrm{~h}, 72 \mathrm{~h}$. Asterisks show means that differ from the control after Dunnett's test at a-level of 0.05 .

final germination percentages. In this sense, it is noticeable that Malo \& Suárez (1996) found that the passage of Cistus ladanifer seeds through the guts of red deer increased the germination percentage respect to the control. Thus, our results suggest that, as in other Cistaceae species, herbivores may promote the germination of $H$. apenninum by virtue of scarification during the digestive processes.

Hardseededness in the Cistaceae has been linked to two processes. First, in view of the burst in germination after fires for many Cistaceae species, hardseededness has been related to the recurrence of fire in the Mediterranean region (Valbuena et al. 1992; Doussi and Thanos, 1993; Ojeda, 2001). Second, given that the passage of seeds through the gut of vertebrates increases germination percentages, it has been suggested that the presence of hard seed coats in the Cistaceae could be related to endozoochorous seed dispersal (Malo and Suárez, 1996, 1998). Our results support this latter hypothesis, as germination in $H$. apenninum is not likely to be benefited by the heat of a fire, but it is promoted by incubation in ruminal liquid. Nevertheless, we should consider that hardseededness is advantageous for maintaining a persistent soil seed bank, a characteristic that is highly appropriate for the viability of plant populations, especially in unpredictable environments such as the Mediterranean (Fenner, 1985; Thompson, 1992). Provided that in nature several mechanisms can erode hard 
seed coats and thus break dormancy (e.g. fungal attack, rainfall wash, mechanical abrasion by soil particles, daily fluctuations in temperature; see Mayer and Poljakoff-Mayber, 1989; Bewley and Black, 1994; Baskin and Baskin, 1998), the possible role of both fire and animals in hardseededness evolution should be taken with caution.

In summary, our results suggest that germination in $H$. apenninum may not be promoted by the heat produced during fires, whereas could be enhanced by herbivore ingestion. The study of more species of Helianthemum as well as of other genera would be appropriate to expand our current knowledge of the effect of these two factors in the germination ecology of this family, and to understand the evolutionary framework of hard seed coats in Cistaceae.

ACKNOWLEDGEMENTS. This research was partly supported by a grant awarded to ABR under the Spanish Government's FPI-MEC post-doctoral programme, and grant from Caja Madrid Foundation to JC. We thank the Consejería de Medio Ambiente for permission to sample within Natural Park of Sierra de Castril, and Drs. E. Molina, J. Boza and Ana T. Romero-García for technical support. Drs. Henry N. Le Houérou, Carlos Passera and Gabriel Blanca gave helpful suggestions that improved the manuscript, and David Nesbitt provided linguistic advice.

\section{REFERENCES}

ARBIZA, S. -1986- Producción de caprinos. AGT Press, México

BASKIN, C.C. \& J.H. BASKIN -1998-Seeds. Ecology, biogeography and evolution of dormancy and germination. Academic Press, San Diego.

BEWLEY, J.D. \& M. BLACK -1994-Seeds. Physiology of development and germination (2nd. ed). Plenum Press, New York.

CASTRO, J. \& A.T. ROMERO-GARCÍA -1999Dormancy and germination in Cistus clusii (Cistaceae): effect of biotic and abiotic factors.
Revue d'Ecologie (Terre et Vie) 54: 19-28.

DOUSSI, M.A. \& C.A. THANOS -1993- The ecophysiology of fire-induced germination in hard-seeded plants. Pp. 445-460 in: Côme, D. \& Corbineau, F. (ed.). Fourth international workshop on seeds. Basic and applied aspects of seed biology, Vol 2. ASFIS, Paris.

ESCUDERO, A., L.F. CARNES \& F. PÉREZGARCÍA - 1997-Seed germination of gypsophytes and gypsovags in semi-arid central Spain. Journal of Arid Environments 36: 487-497.

FENNER, M. -1985- Seed ecology. Chapman and Hall, London.

FERNÁNDEZ, P. -1995-Aprovechamiento silvopastoral de un agrosistema mediterráneo de montaña en el sudeste ibérico. Evaluación del potencial forrajero y la capacidad sustentadora. Ph.D. Thesis, University of Granada, Spain

FERRANDIS, P., J.M. HERRANZ \& J.J. MARTÍNEZSÁNCHEZ - 1999- Fire impact on a maquis soil seed bank in Cabañeros National Park (Central Spain). Israel Journal of Plant Sciences 47: 17-26.

GARDENER, C.J., J.G. McIVOR, \& A. JANSEN 1993a- Passage of legume and grass seeds through the digestive tract of cattle and their survival in faeces. Journal of Applied Ecology 30: 63-74.

GARDENER, C.J., J.G. McIVOR \& A. JANSEN 1993b- Survival of seeds of tropical grassland species subjected to bovine digestion. Journal of Applied Ecology 30: 75-85.

GONZÁLEZ-RABANAL, F. \& M. CASAL - 1995 Effect of high temperatures and ash on germination of ten species from gorse shrubland. Vegetatio 116: 123-131.

GUTTERMAN, Y. \& M. AGAMI -1987- A comparative germination study of seeds of Helianthemum vesicarium Boiss, and $H$. ventosum Boiss., perennial desert shrub species inhabiting two different neigbouring habitats in the Negev desert highlands, Israel. Journal of Arid Environments 12: 215-221.

IBÁÑEZ, A.N. \& C.B. PASSERA - 1997- Factors affecting the germination of albaida (Anthyllis cytisoides L.), a forage legume of the Mediterranean coast. Journal of Arid Environments 35: 225-231. LÓPEZ-GONZÁLEZ, G. -1993-Helianthemun. Pp. 365-421 in: Castroviejo, S., Aedo, C., Cirujano, S., Laínz, M., Montserrat, P., Morales, R., Muñoz-Garmendia, F., Navarro, C., Paiva, J. 
\&Soriano, C. (ed.). Flora Iberica. Vol. 3. CSIC, Madrid.

MALO, J.E. \& F. SUÁREZ -1996- Cistus ladanifer recruitment -not only fire, but also deer. Acta Oecologica 17: 55-60.

MALO, J.E. \& F. SUÁREZ - 1998- The dispersal of a dry-fruited shrub by red deer in a Mediterranean ecosystem. Ecography 21: 204-211.

MARTIN, A., V. GRZESKOWIAK \& S. PUECH 1995- Germination variability in three species in disturbed Mediterranean environments. Acta Oecologica 16: 479-490.

MAYER, A.M. \& A. POLJAKOFF-MAYBER 1989- The germination of seeds (4th ed.). Pergamon Press, Oxford.

MEHREZ, A. \& E. ORSKOV -1977- A study of the artificial fibre bag technique for determining the digestibillity of feeds in the rumen. Journal of Agricultural Science 88: 645-650.

OJEDA, F. -2001- El fuego como factor clave en la evolución de las plantas mediterráneas. Pp. 319349 in: Zamora, R. \& Pugnaire, F.I. (ed.). Ecosistemas mediterráneos. Análisis funcional. Textos Universitarios Vol. 32, CSIC, Granada. OLSON, B.E. \& R.T. WALLANDER -2002- Does ruminal retention time affect leafy spurge seed of varying maturity? Journal of Range Management 55 (1): 65-69.

PEÑA, J., P. APARICIO-TEJO \& M. SÁNCHEZDÍAZ -1988- Dormancy mechanism and the effect of scarification in the germination of Halimium halimifolium seeds. Journal of Plant Physiology 132: 54-58.

PÉREZ- GARCÍA, F. \& A. ESCUDERO -1997Role of the seed coat in germination of Cistus populifolius L. Israel Journal of Plant Sciences 45: 329-331.

PÉREZ-GARCÍA, F., J.M. IRIONDO, M.E. GONZÁLEZ-BENITO, L.F. CARNES, J. TAPIA, C. PRIETO, R. PLAZA \& C. PÉREZ 1995- Germination studies in endemic plant species of the Iberian Peninsula. Israel Journal of Plant Sciences 43: 239-247.

PRINS, R.A. \& C.J.A.H.V. VAN DER VORSTENBOSCH -1975-. Interrelationships between rumen micro-organisms. Pp. 15-24 in: Binnerts, W.T. (ed.). Physiology of digestion. H. Veenman \& Zonen B.V., Wageningen.

PROCTOR, M.C.F. -1978- Cistaceae. Pp. 108-109 in: Heywood, V.H. (ed.). Flowering plants of the world. Oxford University Press, Oxford. ROY, J. \& L. SONIÉ -1992- Germination and population dynamics of Cistus species in relation to fire. Journal of Applied Ecology 29: 647-655.

SIMPSON, R., M.A. LECK \& V.T. PARKER 1989- Seed banks: general concepts and methodological issues. Pp. 3-8 in: Leck, L.A., Thomas V.T. \& Simpson, R.L. (ed.). Ecology of soil seed banks. Academic Press, San Diego

TÉBAR, F.J., L. GIL \& L. LLORENS -1997Reproductive biology of Helianthemum apenninum (L.) Mill. and $H$. caput-felis Boiss. (Cistaceae) from Mallorca (Balearic Islands, Spain). Acta Bot. Malacitana 22: 53-63.

THANOS, C.A., K. GEORGHIOU, C. KADIS \& C. PANTAZI -1992- Cistaceae: a plant family with hard seeds. Israel Journal of Botany 41: 251-263.

THOMPSON, K. -1992- The functional ecology of seed banks. Pp. 231-258 in: Fenner, M. (ed.). Seeds. The ecology of regeneration in plant communities. $\mathrm{CAB}$ International, Wallingford.

TRABAUD, L. -1995- Modalités de germination des cistes et des pins méditerranéens et colonisation des sites perturbés. Revue d'Ecologie (Terre et Vie) 50: 3-14.

TRABAUD, L. \& J. OUSTRIC -1989- Comparaison des stratégies de regénération après incendie chez deux espèces de cistes. Revue d'Ecologie (Terre et Vie) 44: 3-13.

VALBUENA, L., R. TÁRREGA \& E. LUIS -1992Influence of heat on seed germination of Cistus laurifolius and Cistus ladanifer. International Journal of Wildland Fire 2: 15-20.

WHELAN, J.R. -1997- The ecology of fire. Cambridge University Press. Cambridge.

ZAR, J.H. -1996- Biostadistical analysis (3rd. ed.). Prentice Hall, New Jersey.

Aceptado para su publicación en julio de 2002

Dirección de los autores. A.B. ROBLES: Estación Experimental del Zaidín, CSIC, P.O . Box 419. E18008 Granada, Spain. e-mail: abrobles@eez.csic.es; J. CASTRO: Grupo de Ecología Terrestre, Departamento de Biología Animal y Ecología (Unidad de Ecología). Universidad de Granada. E-18071 Granada, Spain. e-mail: jorge@ugr.es. 